\title{
Relation between Serum Leptin, Lipid Profiles and other biomarkers levels in patients with type 2 diabetic nephropathy
}

\author{
Khitam Abdul W. Ali* Esam Noori Al-Kirwi ** \\ Sahar Abdul W-Shaban ***
}

Date of acceptance $1 / 3 / 2010$

\begin{abstract}
:
Background: In advanced diabetes mellitus, serum levels of the most hormones are altered due to several interplaying mechanisms.

Objective: To assess the relation of serum leptin and lipid profile in type 2 diabetic nephropathy.

Patients and Method: Serum leptin levels and its relation to lipid profile were estimated in 62 patients with type 2 diabetic nephropathy attending the National Diabetes Center in Al- Mustansiriya University, and (26) healthy individuals considered as control group.

The diabetic patients were classified into three groups, (24) pathients with normoalbuminuria (21) patients with microalbuminuria and (17) patients with macroalbuminuria.

Fasting plasma glucose, serum creatinine, $\mathrm{Hb} \mathrm{A}_{1} \mathrm{c} \%$, lipid profile (Total cholesterol, LDL- Cholesterol, HDL- Cholesterol and Triglyceride) and urinary albumin, were measured to establish the possibility of using these biomarkers as a supplementary to serum leptin to be a diagnostic test for type 2 diabetic nephropathy.

Results: Serum leptin levels showed a significant elevation in microalbuminuria $(20.08 \pm 4.50 \mathrm{ng} / \mathrm{ml})$ and macroalbuminuria groups $(22.35 \pm 6.89 \mathrm{ng} / \mathrm{ml})$ as compared to nondiabetic normal control group $(10.64 \pm 3.17 \mathrm{ng} / \mathrm{ml})$. There was no significant differences observed in serum leptin levels between the normoalbuminuria group $(13.96 \pm 5.73 \mathrm{ng} / \mathrm{ml})$ and healthy controls, but a significant positive differences were noticed in the levels of fasting plasma glucose, serum creatinine, $\mathrm{Hb} \mathrm{A}_{1} \mathrm{c} \%$ and lipid profile in the three patient groups in comparison with the control group. While no significant correlation was observed between these biomarkers levels and serum leptin values.

Conclusion: It might be concluded that serum leptin levels were elevated in type 2 diabetic patients with microalbuminuria and macroalbuminuria, suggesting that renal leptin degradation is impaired in early stage of kidney damage and this impairment increase with the progression of this disease. Leptin hormone may consider according to these results as a risk factor for progression of kidney disease in diabetic patients.
\end{abstract}

Key words: Leptin Hormone, Diabetic Nephropathy

*Prof. Ass. Ph. D in Clinical Biochemistry/ College of Medicine / Al-Mustansiriya University

** M.B. Ch. B: M.D; C.A.B.M Consultant physician in National Diabetes Center / Al-Mustansiriya

University

*** M. Sc in Clinical Biochemistry/ College of Medicine/ Al-Mustansiriya University 


\section{Introduction:}

In type 2 diabetes, there is a high significant positive correlation between metabolic dysregulation and development of microarnglopathic complications including the subsequent development of renal abnormalities, particularly nephropathy $[1,2]$.

Some studies have examined the association between diabetic mellitus and renal impairment and found that it is difficult to draw a definite conclusion of the complexity of their interrelationships[3,4].

Hormonal factors have been found to play important roles in the development and progression of renal disease in diabetic patients, it can be speculated that, many inflammatory cytokines that secreted by adipose tissue, (including leptin) may be involved partially in promoting renal impairment[5].

Leptin, recently discovered hormone, known as the (satiety) hormone, which involved in the regulation of feeding behavior, metabolic rate, body weight balance and increasing energy expenditure via an interaction with specific leptin receptors located in the hypothalamus[6,7].

It has been reported that circulating leptin increase in chronic renal failure and play a role in patient's weight loss mainly at the end stage renal disease[8].

Hyperlipidemia has been identified as a risk factor for developing a more rapid decline in glomerular filtration rate (GFR) and progression of microalbuminuria in diabetic nephropathy $[9,10]$, and may contribute to the urimic anorexia and malnutrition[11].

Recent study explained the effectiveness of lipid- lowering treatment in decreasing proteinuria and slowing the rate of the (GFR) decline in patients with chronic renal disease [12]. Other study has been shown that intensive blood glucose control effectively prevents the development of microalbuminuria and overt nephropathy in diabetic patients[13].

High triglyceride and low high density lipoprotein- cholesterol has been associated with more rapid progression of microalbuminuria in type 2 diabetes with well controlled blood pressure[14], while hypertriglyceridaemia and hypertension seems to have a synergistic effect on GFR decline[15], and the elevation of plasma leptin concentrations correlate with the severity of renal impairment[16].

It was thought that other diabetic related factors, such as altered renal hemodynamic, excess renal sodium reabsorption and activation of renninangiotensin and sympathetic nervous system may lead to complex interaction between internal physical factors, neurohumoral factors and local mediators (growth factor, cytokines) that ultimately give rise to matrix occumulation, glomerulosselerosis and the loss of nephrons[17].

\section{Patients and Methods}

The present study includes (62) patients with type 2 diabetes mellitus aged (43-62 yrs), (29 females and 33 males) were attending to National Diabetes Center of AL-Mustansiriyah University. There were (26) volunteer subjects (13 females and 13 males), their age range (42-61 yrs), considered as apparently healthy by clinical examination and with no history of any disease

The diabetic patients were classified according to urinary microalbuminuria to creatinine ratio into three groups:-

Group1: Included (24) patients with normoalbuminuria (urinary microalbumin to creatinine ratio $<30$ $\mathrm{mg} / \mathrm{g}$ ). 
Group2: Included (21) patients with microalbuminuria (urinary microalbumin to creatinine ratio30$300 \mathrm{mg} / \mathrm{g}$ ).

Group 3: Included (17) patients with macroalbuminuria (urinary microalbumin to creatinine ratio $>300$ $\mathrm{mg} / \mathrm{g}$ ).

The following Laboratory investigations were done for all patients and control subjects:-

1- Serum Leptin levels were measured in duplicate by radioimmunoassay (DRG Leptin ELISA Kit. Gm bH, Germany).[18]

2- Fasting plasma glucose (FPG)[19], TC[20], TG[21], HDL- C[22] and LDL- C [23] were measured in serum.

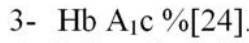

4- Microalbuminuria was determining by a timed (overnight) collection of urine used to measure albumin/ creatinine ratio (Micral test)[25].

\section{Statistical analysis}

Data were analyzed using SPSS (Version 15), the significance of difference was tested using (ANOVA) analysis and statistical test were performed using a null hypothesis of no difference student t-test. The level of significance and P- value were $<0.05$ and $\leq 0.01$.

\section{Results:}

Data analysis of this study showed the mean serum leptin levels in the three groups of type 2 diabetic nephropathy patients were higher than the control group, however, the differences were significant only in patients with microalbuminuria and macroalbuminuria groups $\quad(\mathrm{p}<$
0.05 ), but not significant in the normoalbuminuria group (Table 1). Fasting plasma glucose, $\mathrm{Hb} \mathrm{A}_{1} \mathrm{c} \%$ and serum creatinine levels showed a significant increase in the three patient groups when compared to controls $(p<0.05)$, while there was a significant positive correlation of FPG and $\mathrm{Hb} \mathrm{A}_{1} \mathrm{c} \%$ in all patient groups when compared with healthy control subjects. These results showed that the serum leptin levels did not correlate with FPG, HbAlc \% and serum creatinine levels

$\left(r_{1}=0.105,0.119,0.343\right),\left(r_{2}=\right.$ $0.277,0.270,0.275),\left(r_{3}=0.467\right.$, $0.501,0.223$ ) respectively. (Table 2)

Table (3) shows a significant increase in total cholesterol levels in normoalbuminuria microalbuminuria and macroalbuminuria patient groups when compared to control subjects ( $<<0.005$ ), but there was a difference in levels of serum HDL$\mathrm{C}$ in all patient groups. There is a reduction in serum HDL-C levels in all patient groups when compared to healthy controls, mainly in macroalbuminuria group. Serum levels of LDL-C and TG gave a significant increase in macroalbuminuria and microalbuminuria patient groups as compared to normoalbuminuria and control subjects $(\mathrm{p}<0.05)$.

Table (4) demonstrated that there was a significant positive correlation between total cholesterol and leptin levels in the serum of three patient groups compared to healthy controls, but there was no correlation between $\mathrm{TC}$ and Leptin levels in the serum of all patients groups. $\left(r_{1}=0.023, r_{2}\right.$ $=0.389, \mathrm{r} 3=0.67)$ respectively.

Serum HDL-C, LDL-C and TG levels correlate negatively with 
serum leptin levels in the three patients groups $\left(r_{1}=0.124,0.055\right.$, $0.132), r_{2}=0.051,0.220,0.302$ and $\left(r_{3}=\quad 0.135, \quad 0.188, \quad 0.299\right)$ respectively.

\section{Discussion:}

Diabetic mellitus produces many changes in the glomeruli and lead to diabetic nephropathy and glomerulonephritis which developing chronic renal failure and leads to death[26,27].

The main hypothesis in this study was that if renal filtration is a significant route of hormones elimination, so the hormones [ PRC[28], PTH[29] and GHS[30] ] would accumulate in diabetic nephropathy patients.

Leptin is a new hormone produces by adipocrine, pancrease and other organs by activating transmembrane receptors and in cleared from plasm by the kidney[31].

The present study illustrated that the median serum leptin levels among microalbuminuria (20.08 \pm $4.5 \mathrm{ng} / \mathrm{ml}$ ) and macroalbuminuria $(22.35 \pm 6.89 \mathrm{ng} / \mathrm{ml})$ groups are highly increased comparing to control healthy subjects (10.64 \pm $3.17 \mathrm{ng} / \mathrm{ml}$ ) with highly significant values $(p<0.05)$, but not significant among the normoalbuminuria $(13.96 \pm 5.73 \mathrm{ng} / \mathrm{ml})$ group, as showing in table (1).

These data in accordance to Kanalacry et al. study[32], who predect that serum leptin concentration was significantly higher among patients with type2 diabetic nephropathy compared to non- diabetic controls. Also, Sharma et al [33], in their study on hemodialysis patients found an increase in plasma leptin levels compared to healthy controls.
In addition, the current study showed that there is a positive correlation between fasting plasma glucose, $\mathrm{HbA}_{1} \mathrm{c} \%$ and serum creatinine in all patients when compared to normal controls with highly significant difference $(\mathrm{p}<0.05)$, whereas no correlation appeared between these biomarkers and serum leptin levels. Fu- Mei Chung et al [34] confirmed these results and claimed that plasma leptin levels are not affected by the degree of glycemic control.

Another study by Dafni-Kalliop et $\mathrm{al}[35]$, showed a high elevation in FPG, $\mathrm{Hb} \mathrm{A} \mathrm{A}_{1} \mathrm{c} \%$ and leptin levels in obese patients with renal failure, this elevation may due to insulin resistence, in which leptin reduces insulin secretion and inhances hematopiesis angiogenesis, thermogenesis, diuresis and natriuersis. While Philp et al., [36] and Frank et al.,[37] found an increased in creatinine levels in type 2- diabetic nephropathy patients due to renal impairment.

A point to be noted in the present study was found negative correlation between serum levels of leptin and lipid profile (TC. HDLC, LDL-C and TG) (Table 4). These results indicating that serum TC, LDL-C and TG levels were significantly higher in the three patient groups when compared to normal controls, whereas, there was a decrease in serum HDL-C levels which is a characteristic finding in this disease. Nakazon et $\mathrm{al}[38]$ found that when leptin level increase in blood, plasma insulin levels decreased rapidly and causes a reduction in the expression of target gens participating in fatty acid and cholesterol synthesis. The genes required for reverse cholesterol transport ( including HDL-C and bile acids metabolism) 
are up-regulated by leptin signaling via an unknown mechanism[39]. Leptin has been shown to down regulate hepatichydroxy methyl glutaryl- CoA reductase which leading to a substantial drop in TC and VLDL-C levels in plasma.

The increase in TG levels in circulation in type 2-diabetic nephropathy patients. (hyper triglycerdemia) may due to overproduction of LDL- in the liver and to adiposal defect in the periphery, the latter being the consequence of a deficiency of lipoproteinlipase [40].

\section{Conclusion:}

We conclude that the elevation in leptin serum concentrations are associated with lipid profile in patients with typ 2diabetic nephropathy. This can be possibly used to diagnose patients with type 2- diabetic nephropathy and to identify them with a poor prognosis who may benefit from more aggressive management.

Table (1) : Serum leptin (ng/ml), fasting plasma glucose (mg/dl), $\mathrm{Hb} \mathbf{A}_{1} \mathrm{c} \%$ and creatinine ( $\mathrm{mg} / \mathrm{dl})$ levels in controls and in type 2 diabetic nephropathy groups.

\begin{tabular}{|c|c|c|c|c|}
\hline & \multirow[b]{2}{*}{$\begin{array}{l}\text { Controls } \\
(\mathrm{n}=26)\end{array}$} & \multicolumn{3}{|c|}{ Patients $(\mathrm{n}=62)$} \\
\hline & & $\begin{array}{c}\text { Normoalbuminuri } \\
\text { a } \\
(\mathrm{n}=24)\end{array}$ & $\begin{array}{c}\text { Microalbuminuri } \\
\text { a } \\
(\mathrm{n}=21)\end{array}$ & $\begin{array}{c}\text { Macroalbuminuri } \\
\text { a } \\
(\mathrm{n}=17)\end{array}$ \\
\hline & $\begin{array}{l}\text { Mean } \pm \text { SD } \\
(\text { Min-Max) }\end{array}$ & $\begin{array}{l}\text { Mean } \pm \text { SD } \\
(\text { Min-Max) }\end{array}$ & $\begin{array}{l}\text { Mean } \pm \text { SD } \\
(\text { Min-Max) }\end{array}$ & $\begin{array}{l}\text { Mean } \pm \text { SD } \\
(\text { Min-Max) }\end{array}$ \\
\hline $\begin{array}{l}\text { Leptin } \\
(\mathrm{ng} / \mathrm{ml})\end{array}$ & $\begin{array}{l}10.64 \pm 3.17 \\
(5.10-15.30)\end{array}$ & $\begin{array}{c}13.96 \pm 5.73 \\
(6.70-28.20)\end{array}$ & $\begin{array}{c}20.08 \pm 4.50 \mathrm{ab} \\
(13.00-28.00)\end{array}$ & $\begin{array}{l}22.35 \pm 6.89 \mathrm{ab} \\
(15.00-41.00)\end{array}$ \\
\hline $\begin{array}{l}\text { Fasting plasma glucose } \\
(\mathrm{mg} / \mathrm{dL})\end{array}$ & $\begin{array}{c}77.19 \pm 2.26 \\
(74.00- \\
82.00)\end{array}$ & $\begin{array}{l}156.25 \pm 22.37 \mathrm{a} \\
(120.00-194.00)\end{array}$ & $\begin{array}{l}161.95 \pm 38.77 \mathrm{a} \\
(89.00-247.00)\end{array}$ & $\begin{array}{c}193.29 \pm 61.64 a \\
(120.00-331.00)\end{array}$ \\
\hline $\mathrm{Hb} \mathbf{A}_{1} \mathbf{c} \%$ & $\begin{array}{cc}4.17 \quad \pm 0.12 \\
(4.00- & -4.40) \\
\end{array}$ & $\begin{array}{l}8.10 \pm 1.11 \mathrm{a} \\
(6.30-10.00)\end{array}$ & $\begin{array}{l}8.39 \pm 1.93 a \\
(4.80-12.6)\end{array}$ & $\begin{array}{l}10.08 \pm 3.04 a \\
(6.30-16.80) \\
\end{array}$ \\
\hline $\begin{array}{c}\text { Creatinine } \\
\mathrm{mg} / \mathrm{dL}\end{array}$ & $\begin{array}{cc}0.72 & \pm 0.04 \\
(0.70-0.90)\end{array}$ & $\begin{array}{c}0.87 \pm 0.17 a \\
(0.80-1.50)\end{array}$ & $\begin{array}{c}0.86 \pm 0.11 \mathrm{a} \\
(0.60-1.19) \\
\end{array}$ & $\begin{array}{c}1.26 \pm 0.81 \mathrm{abc} \\
(0.50-4.00)\end{array}$ \\
\hline
\end{tabular}

a- significant difference from control using t-test for two independent mean $(\mathrm{P}<$ 0.05 )

b- significant difference from normoalbuminuria group using t-test for two independent means $(\mathrm{P}<0.05)$

c- significant difference from microalbuminuria group using t-test for two independent means $(\mathrm{P}<0.05)$

Table (2) The correlation coefficient (r) between FPG, $\mathrm{HbA}_{1} \mathrm{c} \%$, creatinine and leptin levels in controls and in patient groups, and their $\mathrm{P}$-value.

\begin{tabular}{|c|c|c|c|c|c|}
\hline \multicolumn{2}{|c|}{} & \multirow{2}{*}{$\begin{array}{c}\text { Controls } \\
(\mathrm{n}=26)\end{array}$} & $\begin{array}{c}\text { Normoalbuminuria } \\
(\mathrm{n}=24)\end{array}$ & $\begin{array}{c}\text { Microalbuminuria } \\
(\mathrm{n}=21)\end{array}$ & $\begin{array}{c}\text { Macroalbuminuria } \\
(\mathrm{n}=17)\end{array}$ \\
\cline { 3 - 6 } & & $\begin{array}{c}\text { Leptin } \\
(\mathrm{ng} / \mathrm{ml})\end{array}$ & $\begin{array}{c}\text { Leptin } \\
(\mathrm{ng} / \mathrm{ml})\end{array}$ & $\begin{array}{c}\text { Leptin } \\
(\mathrm{ng} / \mathrm{ml})\end{array}$ & $\begin{array}{c}\text { Leptin } \\
(\mathrm{ng} / \mathrm{ml})\end{array}$ \\
\hline \multirow{2}{*}{$\begin{array}{c}\text { Fasting plasma } \\
\text { glucose }(\mathrm{mg} / \mathrm{dL})\end{array}$} & $\mathrm{r}$ & 0.259 & 0.105 & 0.277 & 0.467 \\
\hline \multirow{2}{*}{$\mathrm{HbA}_{1} \mathrm{c} \%$} & $\mathrm{p}$ & 0.201 & 0.982 & 0.224 & 0.059 \\
\cline { 2 - 6 } & $\mathrm{p}$ & 0.256 & 0.982 & 0.270 & 0.501 \\
\hline \multirow{2}{*}{$\begin{array}{c}\text { Creatinine } \\
\mathrm{mg} / \mathrm{dL}\end{array}$} & $\mathrm{r}$ & 0.058 & 0.156 & 0.236 & 0.011 \\
\cline { 2 - 6 } & $\mathrm{p}$ & 0.779 & 0.468 & 0.315 & 0.562 \\
\hline
\end{tabular}

Correlation is significant at the 0.05 level (2.tailed) 
Table (3) : Mean values of serum total cholesterol, HDL- C, LDL- C and TG levels in controls and in patient groups.

\begin{tabular}{|c|c|c|c|c|}
\hline & \multirow[b]{2}{*}{$\begin{array}{l}\text { Controls } \\
(\mathrm{n}=26)\end{array}$} & \multicolumn{3}{|c|}{ Patients $(\mathrm{n}=62)$} \\
\hline & & $\begin{array}{c}\text { Normalbuminuria } \\
(\mathrm{n}=24)\end{array}$ & $\begin{array}{l}\text { Microalbuminuria } \\
(\mathrm{n}=21)\end{array}$ & $\begin{array}{c}\text { Macroalbuminuria } \\
(\mathrm{n}=17)\end{array}$ \\
\hline & $\begin{array}{l}\text { Mean } \pm \text { SD } \\
\text { Min-Max) }\end{array}$ & $\begin{array}{l}\text { Mean } \pm \text { SD } \\
\text { Min-Max) }\end{array}$ & $\begin{array}{c}\text { Mean } \pm \text { SD } \\
\text { Min-Max) }\end{array}$ & $\begin{array}{c}\text { Mean } \pm \text { SD } \\
\text { Min-Max) }\end{array}$ \\
\hline $\begin{array}{c}\text { Total cholesterol } \\
(\mathrm{mg} / \mathrm{dl})\end{array}$ & $\begin{array}{c}142.42 \pm 26.87 \\
(100.00-190.00)\end{array}$ & $\begin{array}{c}182.67 \pm 25.51 \mathrm{a} \\
(100.00-208.00)\end{array}$ & $\begin{array}{l}195.14 \pm 40.32 \mathrm{a} \\
(95.00-246.00)\end{array}$ & $\begin{array}{c}200.82 \pm 34.05 \mathrm{a} \\
(120.00-240.00)\end{array}$ \\
\hline $\mathrm{HDL}-\mathrm{C}(\mathrm{mg} / \mathrm{dL})$ & $\begin{array}{c}47.50 \pm 8.20 \\
(35.00-62.00)\end{array}$ & $\begin{array}{c}43.08 \pm 14.35 \\
(21.00-70.00)\end{array}$ & $\begin{array}{c}41.43 \pm 8.53 \\
(25.00-55.00)\end{array}$ & $\begin{array}{c}40.18 \pm 12.11 \\
(22.00-71.00)\end{array}$ \\
\hline $\mathrm{LDL}-\mathrm{C}(\mathrm{mg} / \mathrm{dL})$ & $\begin{array}{c}85.15 \pm 19.49 \\
(59.00-145.00)\end{array}$ & $\begin{array}{c}89.38 \pm 11.93 \\
(72.00-113.00)\end{array}$ & $\begin{array}{c}102.71 \pm 28.56 \mathrm{ab} \\
(70.00-165.00)\end{array}$ & $\begin{array}{l}111.00 \pm 24.62 \mathrm{ab} \\
(62.00-145.00)\end{array}$ \\
\hline Triglyceride(mg/dL) & $\begin{array}{c}93.69 \pm 28.12 \\
(51.00-155.00)\end{array}$ & $\begin{array}{c}94.38 \pm 18.83 \\
(47.00-131.00)\end{array}$ & $\begin{array}{l}152.95 \pm 36.27 \mathrm{ab} \\
(175.00-200.00)\end{array}$ & $\begin{array}{c}201.18 \pm 54.48 \mathrm{abc} \\
(120.00-350.00)\end{array}$ \\
\hline
\end{tabular}

Table (4) : The correlation coefficient (r) between serum TC, HDL-C, LDL-C and TG with levels in controls and in patient groups, and their $P$-values

\begin{tabular}{|c|c|c|c|c|c|}
\hline \multirow{2}{*}{} & \multirow{2}{*}{$\begin{array}{c}\text { Controls } \\
(\mathrm{n}=26)\end{array}$} & $\begin{array}{c}\text { Normoalbuminuria } \\
(\mathrm{n}=24)\end{array}$ & $\begin{array}{c}\text { Microalbu } \\
\text { minuria } \\
(\mathrm{n}=21)\end{array}$ & $\begin{array}{c}\text { Macroalbuminuria } \\
(\mathrm{n}=17)\end{array}$ \\
\cline { 3 - 6 } & & $\begin{array}{c}\text { Leptin } \\
(\mathrm{ng} / \mathrm{ml})\end{array}$ & $\begin{array}{c}\text { Leptin } \\
(\mathrm{ng} / \mathrm{ml})\end{array}$ & $\begin{array}{c}\text { Leptin } \\
(\mathrm{ng} / \mathrm{ml})\end{array}$ & $\begin{array}{c}\text { Leptin } \\
(\mathrm{ng} / \mathrm{ml})\end{array}$ \\
\hline \multirow{2}{*}{$\begin{array}{c}\text { Total cholesterol } \\
(\mathrm{mg} / \mathrm{dl})\end{array}$} & $\mathrm{r}$ & 0.201 & 0.023 & 0.382 & 0.067 \\
\cline { 3 - 6 } & $\mathrm{p}$ & 0.324 & 0.914 & 0.088 & 0.985 \\
\hline \multirow{2}{*}{$\mathrm{HDL}-\mathrm{C}(\mathrm{mg} / \mathrm{dL})$} & $\mathrm{r}$ & -0.052 & -0.124 & 0.051 & -0.135 \\
\cline { 2 - 6 } & $\mathrm{p}$ & 0.801 & 0.563 & 0.825 & 0.606 \\
\hline \multirow{2}{*}{ LDL-C(mg dL) } & $\mathrm{r}$ & 0.103 & 0.055 & 0.220 & 0.271 \\
\cline { 2 - 6 } & $\mathrm{p}$ & 0.616 & 0.797 & 0.337 & 0.292 \\
\hline \multirow{2}{*}{$\mathrm{TG}(\mathrm{mg} \mathrm{dl})$} & $\mathrm{r}$ & 0.090 & 0.130 & 0.302 & 0.299 \\
\cline { 2 - 6 } & $\mathrm{p}$ & 0.661 & 0.544 & 0.183 & 0.244 \\
\hline
\end{tabular}

Correlation is significant at the 0.05 level (2.tailed).

\section{References:-}

1- Chen J., Muntner P., Hamm L.L., Jones D, DW, Batuman V, Fonseca $\mathrm{V}$, Whelton $\mathrm{P} \mathrm{K}$. The metabolic syndrome and chronic kidney disease in US adults. Ann Intern Med. (2004). $140: 167-174$.

2- Diabetes control and complications trial research group: Clustering of long-term complications in families with diabetes in the Diabetes Control and Complications Trial. Diabetes. (1997) 46 : 1826-1839

3- Hoehner C. M., Greenlund K.J., Rith-Najarian S., Casper M.L., Mcclellan W.M. Association of the insulin resistance syndrome and microalbuminuria among nondiabetic native Americans. The Inter Trial Heart Peoject. J. Am Soc Nephrol. (2003) 13 : 16261634.
4- Francesco L, Pietro P and Lucia D V. Renal manifestations in the metabolic syndrome. J Am Soc Neophrol (2006) 17: 81-85.

5- Wisse BE : The inflammatory syndrome: the role of adipose tissue cytokines in metabolic disorders linked in obesity. J Am Sec Nephrol (2004) 15: 2792-2800.

6- Barash IA, Cheung C C, Weigle DS, Ren $\mathrm{H}$, Kabigting EB, Kuijer J L, Clifton DK, Steiner RA. Leptin is a metabolic signal to the reproductive system. Endocrinology. (1996). 137 : 31443147.

7- Meister B. Control of food intake via leptin receptor in the hypothalamus. Vitam Horm. (2000). 59: 265-304

8- Odamki M, Furuya R, Yoneyama T et al. Association of serum leptin concentration with weight loss in chronic hemodialysis patients. Am 
J Kideny Dis. (1999) 33(2) : 361368.

9- Adelman R. Obesity and renal disease. Curr opin Nephrol hypertens. (2002) 11:331-335.

10- Hostetter TH. Diabetic nephropathy. New Engl $\mathrm{J}$ Med (1985) $312: 642-644$.

11- Mulec H, Johnson SA, Bjoks. Relation between serum cholesrerol diabetic nephropathy, Lancet. (1999) 335 : 1537-1538.

12- Fried LF, Orchard TJ, Kasiaker BL. Effect of lipid reduction on the progression of renal disease. A meta- analysis. Kidney Int. (2001) $59:$ 266-269.

13- Patterson BW, Klins, Martin DR. Whole body leptin kinetics and renal metabolism in vitro. Am $\mathrm{J}$ Physiol Endocrinol Metlab. (1997) $273: 1102-1106$.

14- Ravid M, Neumann L, Lishner M : Plasma lipids and the progression of nephropathy in diabetes mellitus. Kidney. Int, (1995), 47:907-910.

15- Nielson S, Schmitz O, Moller N, et. al. Renal function and insulin sensitivity during simvastation treatment in type 2 (non insulin dependent) diabetic patients with microalbuminuria. Diabetologia (1993), 36 : 1079-1086.

16- Biesenbach G, Zazgornich J. Lovastatin in the treatment of hypercholesterolemia in nephritic syndrome due to diabetic nephropathy stage IV-V. Clini. Nephrol, (1992), 37: 274-279.

17- Hall JE, Brands MW, Henegar JR. Mechanisms of hypertension and kidney disease in obesity. Ann NY Acad Sci. (1999). 892: 91-107.

18- Scholze A., Rattensperger. D., Zidek W., Tepel M. Low serum leptin predicts mortality in patients with chronic kidney disease stage 5. obesity. (2007) 15 (6): 16171622 .
19- Tietz. N W. et. al. Clinical Guide to laboratory tests. $3^{\text {rd }}$ edition (1995).

20- Fossali R. and prencipe L. Clin Chem., (1982)., 28: 2077.

21- Naito HK, Cholesterol. Kaplan A et.al. Clin Chem. The C. V. Mosby Co. St Louis Toronto. Princeton., Clin Chem. (1984) 437: 11941206.

22- Wild RA, Alaupovic P, Parker I J. Lipid and a polipoprotien abnormalities in hirsute women. Am J obstet Gynecol. (1992) : 166: 1191-1196.

23- Legro RS, Blanche P, Krauss RM, Lobo RA. Alteration in low density lipoprotein and high- density lipoprotein subclasses among Hispanic women- with polycystic ovary syndrome. Fertilsteril. (1999); 72: 990-995.

24- Rohlfing C. L., Wiedmeyer H. M. and Little R.R. The relationship between plasma glucose and $\mathrm{HbA}_{1}$ c. Diabetes care. (2002) : 25 : 275-278

25- Pugia MJ. et. al : Comparison of urine dipsticks with quantitative methods for microalbuminuria. Euro J. Clin. Chem. Biochem. (1997) 35 (9): 693-700.

26- Position statement : Diabetic nephropathy. Diabetes care (1997). $20: 24-27$

27- Jays. Skyler, MD. Guest Editor, et.al : Prevention and treatment of diabetes and its complications. Medical Clinics of North Americal, (1998), 82: 877-880.

28- Bayliss D. Prolactin. Medical Pharmacology (2003) 11: 1-2.

29- Fostave VT, Sayegh MH, Hickey N, Aliabadr P, Lazarus JM, Lebolf Ms. Intact parathyroid hormone levels in renal insufficiency. Calcif Tissue Int. (1995) 57: 339-335.

30- Gibney J, Healy L. M. and Sonksen H.P. Growth hormone and 
exercise. The Endocrine Society. (2007) 10; 1210.

31- Eddine M., Samul DJ., Daniel WC., Samuel K., Julio VS., Paul SH. And Michael L Increased plasma leptin concentration in end stage renal disease. J. Clinic Endoc and Metab. (1997). 82 (3) : 847850.

32- Kanalaery J., Fenicchia M., Miller Cs et.al. Resting serum leptin responses the acute and chronic reistance training in type 2 diabetic men and women. Int. J. Relat. Metab Disorders. (2001) 25 (10) : 80-1474.

33- Sharmak., Considine R., Beckie M et.al., Plasma leptin is partly cleared by the kidney and is elevatied in hemodialysis patients. Kidney Int. (1997) 51: 980-985.

34- Fu-Mci Chung MS., Jack C. et.al. Peripheral total and differential leukocycte count in diabetic nephropathy. The relationship of plasma leptin to leukocytosis. Diabetes care. (2005). 28: 17101717.

35- Dafni- Kalliop, Papafrakaki, George T: Obesity and renal disease : A possible role of leptin. Hormones. (2005) 4(2) : 90-95.

36- Philp MH., Prevention of Progression in diabetic nephropathy. Diabetes spectrum (2006) 19: 18-24.

37- Frank P., Kay H. et. al., Rosigli tazone improves glomeluar hyperfiltration, renal endothelial dysfunction, and microalbuminuria of incipent diabetic nephropathy in patients. Diabetics (2005) 54: 2206-2211.

38- Nakazona H., Nagake Y., Ichihkawa H.Serum leptin concentration in patients on hemodialysis Nephron (1998). 80(1): $35-40$.

39- Liang $\mathrm{CP}$ and Tall AR. Transcriptional profiling reveals global defects in energy metabolism, lipoprotein, and bile acid synthesis and transport with reveres by leptin treatment in ob/ob mous liver. J. Biol. Chem. (2001) 276 (52): 4966-4976.

40- Taskinen MR., Quantitaive and qualitative lipoprotein abnormalities in diabetes mellitus Diabetes (1992) 41(2) 12-17. 


\section{علاقة مستوى اللبتين مع شاكلة الدهون وبعض المتغيرات الكيمياحياتية في مصل باعل الكيل لدم مرضى السكري من النمط الثاني المصاحب بأعتلال الكلى الكئ}

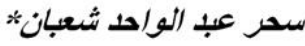

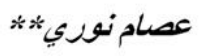

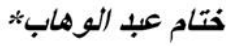

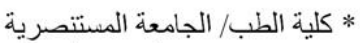

** مركز امر اض السكر / الجامعة المستتصرية

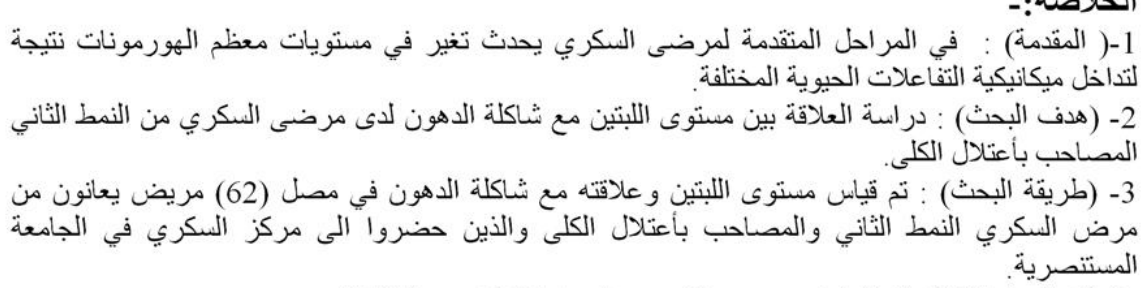
وشملت الدراسة كذلك (26) شخص سوي (كمجمو عة ضابطة) لغرض المبن المقارنة

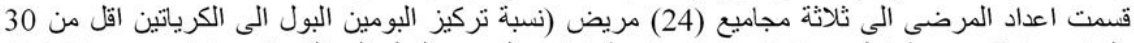

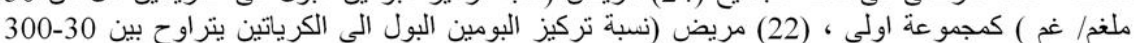

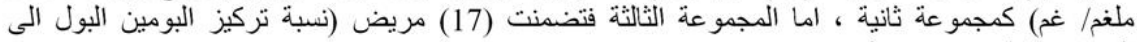

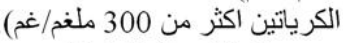
تم قياس تراكيز كل من الكرياتين ، شاكلة الدهون والتي تشمل التئل (الكوليسترول الكلي ، كوليسترول

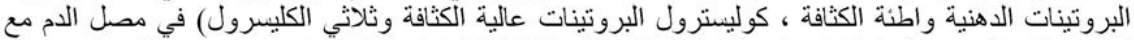

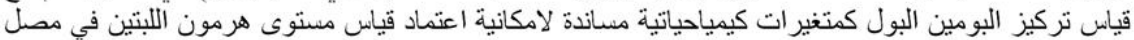

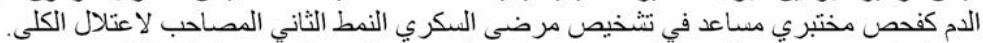

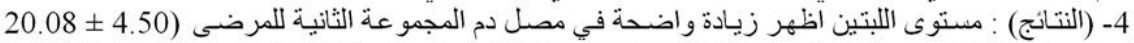

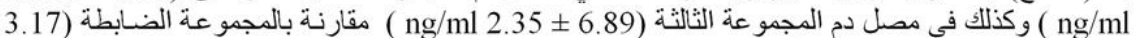

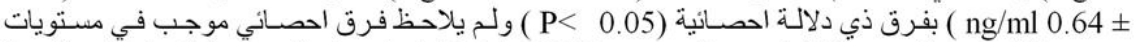

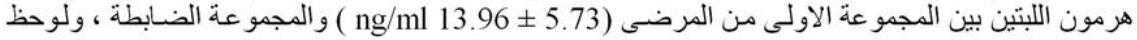

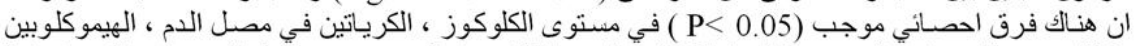

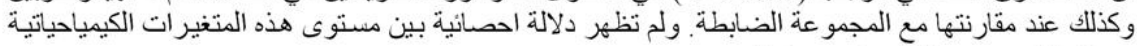

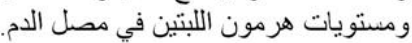

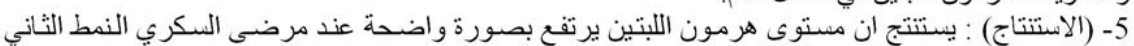

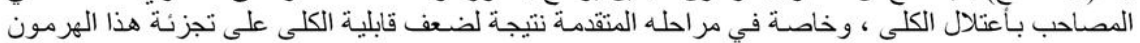

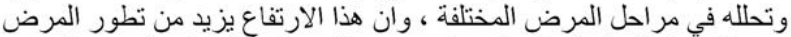

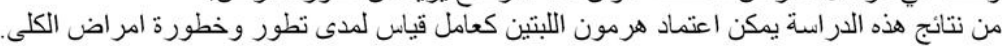

